A N N A L ES

UNIVERSITATIS MARIAE CURIE-SKŁODOWSKA

LUBLIN - POLONIA

VOL. LXVI, 2

SECTIO G

2019

Uniwersytet Warszawski

CEZARY BŁASZCZYK

c.blaszczyk@wpia.uw.edu.pl

ORCID: 0000-0003-4095-600X

\title{
Federalizacja jako środek do rozwiązania konfliktów na Bliskim Wschodzie. Przypadek Demokratycznej Federacji Północnej Syrii
}

Federalization as a Mean to Resolve Conflicts in the Middle East.

The Case of the Democratic Federation of Northern Syria

\section{WPROWADZENIE}

Truizmem byłoby stwierdzenie, że Bliski Wschód jest regionem doświadczanym przez liczne konflikty międzypaństwowe i wewnętrzne, w tym napięcia na tle etnicznym i religijnym. W regionie panuje deficyt demokracji. Najczęściej spotykaną formą rządów są różnego rodzaju autorytaryzmy oparte na zasadzie centralizmu, interwencjonizmu, a także dominacji wybranego ośrodka politycznego czy grupy narodowej i wyznaniowej. W większości przypadków trudno mówić o społeczeństwie obywatelskim. $Z$ jednej strony mamy do czynienia $\mathrm{z}$ wycofaniem obywatelskim, $\mathrm{z}$ drugiej - z brakiem zrozumienia dla idei demokracji i rządów prawa. Wręcz oczekuje się, iż system polityczno-prawny będzie miał charakter ekskluzywistyczny, służąc interesom wybranej grupy (np. w formie assabiji, czyli swoistego klientelizmu).

Kontrowersji nie powinno budzić także spostrzeżenie, że dotychczas nie znaleziono uznanego i skutecznego sposobu na przezwyciężenie opisywanej sytuacji. W kontekście łagodzenia napięć formułuje się jednak rozmaite teorie odwołujące się do trzech czynników: stosunków gospodarczych, uwarunkowań kulturowych (w tym ideologii) oraz zagadnień ustrojowych. Pośród nich coraz częściej wskazywany jest federalizm¹.

1 Zob. np. M. Versteeg, Federalism in the Middle East. A Collection of Essays, www.lawfareblog.com/federalism-middle-east-collection-essays [dostęp: 10.09.2018]; C. Mallat, Federalism in 
Trzeba jednak zaznaczyć, iż federalizm, do którego odwołują się adherenci przywoływanego programu, różni się od tzw. federalizmu klasycznego, związanego z wertykalnym podziałem władzy - tak jak ujęto to choćby w porządku amerykańskim czy australijskim. Jest to federalizm nowego typu, który możemy tu określić federalizmem drugiej fali, „etnofederalizmem” albo „federalizmem czasu powojennego”, jak czyni się to w literaturze przedmiotu². Ta forma organizacji politycznej dedykowana jest bowiem państwom dokonującym transformacji ustrojowej (demokratyzującym się), postkolonialnym, zróżnicowanym etnicznie czy wręcz wewnętrznie zantagonizowanym, nierzadko wdrażającym program pokojowy po konflikcie wewnętrznym. Czerpiąc z doświadczeń i rozwiązań systemowych takich państw, jak Belgia, Szwajcaria czy Kanada, jej celem jest stabilizacja, eliminacja napięć i studzenie tendencji separatystycznych. Federalizm terytorialny uzupełniany jest $w$ tym wypadku o federalizm segmentowy, czyli (notabene postulowany w innej formie już przez Monteskiusza) społeczny podział władzy.

Prima facie opisywane rozwiązanie rzeczywiście ma potencjał, by gasić napięcia i niwelować pęd dyskryminowanych mniejszości ku ustanowieniu odrębnego państwa. Oferuje ono jedność bez jednolitości czy raczej bez ujednolicania. Powołując do istnienia autonomię regionalną, zbliża obywateli do władzy. Zapewnia też udział w samorządzie i umożliwia kontrolę poczynań władz przedstawicielskich. Stymuluje zatem rozwój społeczeństwa obywatelskiego i czyni ze sfederalizowanej republiki wielkie laboratorium demokracji. Znacznie istotniejszy podział władzy pomiędzy komponenty społeczne (np. poprzez zagwarantowanie każdemu $\mathrm{z}$ nich odpowiedniej reprezentacji w parlamencie bądź wprost rozdzielenie pomiędzy nimi organów) ma z kolei umożliwić pokojowe współistnienie oraz zapewnić równy status wszystkich grup etnicznych i wyznaniowych (zastosowane instytucje nie pozostają jednak bez znaczenia dla powodzenia projektu i stanowią przedmiot debaty w literaturze przedmiotu ${ }^{3}$ ). W konsekwencji federalizm nowego typu nie odnosi się wyłącznie do podziału geograficznego, lecz także do podziału etnicznego, i możliwy jest do realizacji na terytorium, na którym przenikają się rozmaite wspólnoty ${ }^{4}$.

the Middle East and Europe, "Case Western Reserve Journal of International Law" 2003, Vol. 35(1), s. 1 i n.; D.J. Elazar, Exploring Federalism, Tuscaloosa-London 1987, s. 10.

2 S. Choudhry, N. Hume, Federalism, Devolution and Secession: From Classical to Post-conflict Federalism, [w:] Handbook on Comparative Constitutional Law, eds. T. Ginsburg, R. Dixon, Cheltenham-Northhampton 2011, s. 363 i n.; H. Hale, Divided We Stand. Institutional Sources of Ethnofederal State Survival and Collapse, "World Politics" 2004, Vol. 56(2), DOI: https://doi.org/10.1353/wp.2004.0011, s. 165; P.G. Roeder, Ethnofederalism and the Mismanagement of Conflicting Nationalisms, "Regional \& Federal Studies" 2009, Vol. 19(2), DOI: https:// doi.org/10.1080/13597560902753420, s. 203.

3 Szerzej debate tę omawiają Sujit Choudhry i Nathan Hume (op. cit., s. 364 i n.).

4 Y. Ghai, Ethnicity and Autonomy. A Framework for Analysis, [w:] Autonomy and Ethnicity. Negotiation Competing Claims in Multi-ethnic States, ed. Y. Ghai, Cambridge 2000, s. 8 i n.; 
Jednocześnie etnofederalizm bywa krytykowany jako prowadzący do zaostrzania napięć, a więc stanu, któremu ma przeciwdziałać. Przyznanie komponentom autonomii regionalnej zdaniem sceptyków ma prowadzić do postępującego dystansowania się kultur i rozbicia społecznego, a niekiedy również może skutkować paraliżem decyzyjnym i osłabianiem państwa. Konsekwencją tego stanu rzeczy są tendencje centralizacyjne i separatystyczne, które napędzając się wzajemnie, grożą wybuchem otwartego konfliktu. Wystarczy tu przywołać przykład Jugosławii i wojny, która zwieńczyła jej rozpad. Do badaczy podkreślających wady omawianej koncepcji należy m.in. Philip G. Roeder 5 .

Nie bez znaczenia są też uwarunkowania podyktowane kulturą polityczną Bliskiego Wschodu. W krajach arabskich i muzułmańskich do idei federalizacji podchodzi się podejrzliwie, kojarząc ją z interwencjonizmem międzynarodowym mocarstw arbitralnie wyznaczających granice pomiędzy poszczególnymi państwami. Traktowana jest również jako przejaw partykularyzmu i rozkładu państwa, jako przeciwieństwo przygasłego panarabizmu czy wciąż żywej koncepcji islamskiej ummy (tj. wspólnoty wiernych). Poza tym nie ma głębszych tradycji federalistycznych $\mathrm{w}$ arabskiej nauce prawa, jako że systemy prawa pozytywnego stanowią dziedzictwo okresu kolonialnego, a konstytucjonalizmy sprawujących mandat $\mathrm{w}$ regionie Wielkiej Brytanii i Francji nie zawierają idei federalizacji. Nieśmiałe koncepcje, często zresztą zakamuflowane, proponowane są w Libanie, Libii czy Jemenie, lecz jak dotąd bez powodzenia.

Warto dodać, że niepowodzeniem zakończyła się większość dotychczasowych prób federalizacji Bliskiego Wschodu. Choć jako jedna z najstarszych form ustrojowych federacja występowała w regionie przed tysiącami lat (np. jako federacja plemion Izraela, o których wspomina Stary Testament), to renesans tej formy w drugiej połowie XX w. zupełnie się nie powiódł. Przyczyną był charakter powoływanych wówczas struktur. W przypadku Federacji Arabskiej czy Federacji Republik Arabskich celem była realizacja panarabizmu i zwiększenie potęgi państwa, a nie dążenie do konsensu społecznego i stworzenia autentycznej demokracji uzgodnieniowej. Z kolei takie twory, jak Federacja Arabii Południowej stanowiły formę pośrednią na drodze transformacji kolonii do niepodległych państw. W chwili powstania już były skazane na tymczasowość.

A. Lijphart, Democracy in Plural Societies. A Comparative Exploration, New Haven-London 1977, s. 8 i n.; J. McGarry, B. O'Leary, Must Pluri-national Federations Fail?, "Ethnopolitics" 2009, Vol. 8(1), DOI: https://doi.org/10.1080/17449050902738838, s. 5 i n. Por. D. Horowitz, Making Moderation Pay. The Comparative Politics of Ethnic Conflict Management, [w:] Conflict and Peacemaking in Multiethnic Societies, ed. J.V. Montville, Lexington 1990, s. 451-475; W. Kymlicka, Federalism and Secession. At Home and Abroad, "Canadian Journal of Law and Jurisprudence" 2000, Vol. 13(2), DOI: https://doi.org/10.1017/S0841820900000400, s. 207-224.

5 P.G. Roeder, op. cit., s. 203 i n. Por. W. Kymlicka, Is Federalism a Viable Alternative to Secession, [w:] Theories of Secession, ed. P.B. Lehning, London-New York 1998, s. 109-148. 
W konsekwencji federalizm funkcjonuje dziś na Bliskim Wschodzie zaledwie w Zjednoczonych Emiratach Arabskich i Iraku. W pierwszym przypadku mamy jednak do czynienia $\mathrm{z}$ federacją emiratów, a więc krajów o ustroju monarchicznym, a nie republikańskim. Forma ustrojowa tego państwa nie może więc pretendować do miana odpowiedzi na problemy poruszone powyżej. Jedyną federacją aspirującą do miana demokracji w regionie pozostaje zatem utworzona w 2005 r. Republika Iraku. Co istotne, wiele dzieli jeszcze system iracki od stabilizacji i dojrzałości, którą obiecuje wybrana forma ustrojowa.

Pomimo to uważam, że omawiana koncepcja nie powinna zostać odrzucona, a państwem na Bliskim Wschodzie, które w szczególności zasługuje na bliższe omówienie, jest Syria. Owszem, wdrożenie federalizmu byłoby w tym przypadku bez wątpienia niełatwym przedsięwzięciem, lecz jednocześnie wyjątkowo adekwatnym i obiecującym. Po pierwsze, stanowiłoby formę pokojowej transformacji ustrojowej w warunkach znacznego rozbicia politycznego, etnicznego i wyznaniowego. Byłoby więc alternatywą dla autorytaryzmu Syryjskiej Republiki Arabskiej i brutalnej wojny domowej, której to państwo doświadcza (właściwie mogłoby wręcz rozwiązać ten konflikt). Po drugie, formuła regionalnych autonomii wypracowana przez główne siły polityczne oraz komponenty etniczne i religijne realizowałaby ideę konsensu powszechnego ${ }^{6}$. Innymi słowy, federalna forma ustrojowa potencjalnie łagodziłaby wewnętrzne napięcia, umożliwiając pokojową kooperację poszczególnych grup oraz zapewniając im dostateczną autonomię. Po trzecie, opisywany projekt został już zaproponowany przez jeden z istotnych ośrodków politycznych w tym kraju. Może więc być szansą na endogeniczną (a nie narzuconą z zewnątrz, jak w przypadku Iraku), stopniową demokratyzację kraju i budowę dojrzałego społeczeństwa obywatelskiego. I wreszcie po czwarte, uznanie autonomii Północnej Syrii byłoby dla prześladowanych od wieków Kurdów, którzy zamieszkują tę prowincję, wielkim zwycięstwem i szansą na normalne, wolne od prześladowań życie. Jest to aspekt wykraczający poza przedmiot niniejszego opracowania, ale bez wątpienia wart odnotowania.

W tym miejscu należy pokrótce przedstawić zarówno ośrodek polityczny opowiadający się za federalizacją i demokratyzacją Syrii, jak i proponowaną przez niego koncepcję. Mowa oczywiście o Demokratycznej Federacji Północnej Syrii (DFNS) ${ }^{7}$, znanej szerzej jako Zachodni Kurdystan albo Rożawa (kurd. rojava - 'zachód', dosł. 'tam, gdzie zachodzi słońce') $)^{8}$. Jest to de facto autono-

6 Należy jednak nadmienić, że chociaż napięcia na tle etnicznym bez wątpienia stanowią w Syrii problem (np. w formie prześladowań Kurdów na północy kraju) i potencjalne źródło destabilizacji, to nie one były powodem ,wybuchu” wojny domowej. Początkowo konflikt miał podłoże stricte polityczne.

7 DFNS - ang. Democratic Federation of Northern Syria, kurd. Federaliya Demokratîk a Bakure Suriye, pol. Demokratyczna Federacja Północnej Syrii.

8 Od września 2018 r. w użyciu jest też nazwa Demokratyczna Federacja Północnej i Wschodniej Syrii, oddająca przekształcenia terytorialne autonomii ostatnich miesięcy. 
mia powstała w 2012 r. na północnym wschodzie Syrii na skutek wycofania się większości sił syryjskich na południe kraju9 . Oddziały kurdyjskie rozbroiły wówczas pozostałych na miejscu funkcjonariuszy, przejęły władzę i przystąpiły do realizacji szeroko zakrojonego programu socjalizmu libertarnego (tzw. Rewolucja w Rożawie). W 2014 r. proklamowano formalną autonomię ze stolicą w Kamiszlo (kurd. Qamişlo), znanym też jako Al-Kamiszli. W jej skład wchodzą trzy samorządne regiony: Dżazira (kurd. Cizîrê), Eufrat (kurd. Firatê) i Afrin (kurd. Efrînê), do 2017 r. nazywane - na wzór Konfederacji Szwajcarskiej - kantonami. Obecnie (wrzesień 2018 r.) Afrin i część Eufratu znajdują się jednak pod okupacją armii tureckiej i sprzymierzonych z nią bojówek islamistycznych. Z kolei w toku kampanii wymierzonej przeciw tzw. Państwu Islamskiemu Kurdom udało się wyzwolić cztery dodatkowe dystrykty, na których powołano tymczasową administrację.

Podobnie jak cała Syria, Rożawa charakteryzuje się szczególnym bogactwem kultur. Oprócz Kurdów żyją tam Arabowie, Asyryjczycy, Ormianie, Czeczeni, Turkmeni, a nawet Domowie. Jeżeli chodzi o grupy wyznaniowe, to poza dominującym islamem sunnickim spotkać można reprezentantów szyizmu, a także alawitów, chrześcijan rozmaitych obrządków, jezydów i zaratusztrian. Niemal każda z tych grup posiada własną reprezentację polityczną, niekiedy również militarną, a podział demograficzny sprawia, że poszczególne formacje rezydują w osobnych prowincjach. Co więcej, wyjątkowe rozbicie polityczne cechuje samych Kurdów, którzy tworzą miriady rozmaitych ugrupowań. Upraszczając, wszystkie partie dzielą na dwa obozy: akceptujących rządy Partii Unii Demokratycznej (PYD) ${ }^{10}$ bądź je tolerujących (jako uczestników systemu) oraz kontestujących władzę i system (formacje związane ze znajdującą się pod wpływem Kurdyjskiego Rządu Regionalnego w Iraku ${ }^{11}$ Kurdyjską Radą Narodową $\left.{ }^{12}\right)$.

W tym stanie rzeczy PYD i jej koalicjanci zdecydowali się w grudniu $2016 \mathrm{r}$. przekształcić Rożawę (utożsamianą z nacjonalizmem kurdyjskim) w szerszy projekt polityczny, który (przynajmniej w sferze deklaracji) byłby inkluzywny wobec niekurdyjskich mniejszości etnicznych oraz ugrupowań odrzucających proponowany socjalizm. Powołano wówczas Federację wszystkich ludów zamieszkujących terytorium Północnej Syrii (DFNS), która ma być jednocześnie częścią składową przyszłej (postulowanej) Federacji ogólnosyryjskiej i modelem wzorco-

9 Federacja zajmuje nieciągłe terytorium, które ze względu na toczącą się wojnę z tzw. Państwem Islamskim oraz Republiką Turecką wciąż się zmienia. W szczytowym momencie w 2017 r. łączna powierzchnia Rożawy w przybliżeniu odpowiadała powierzchni Belgii.

10 PYD - kurd. Partiya Yekîtiya Demokrat, pol. Partia Unii Demokratycznej (Partia Jedności Demokratycznej, Unia Demokratyczna).

11 KRG (HHK) - ang. Kurdish Regional Government, kurd. Hikumetî Heremî Kurdistan, pol. Rząd Autonomicznego Regionu Kurdystanu (Kurdyjski Rząd Regionalny).

12 ENKS (KNC) - kurd. Encumena Niştimanî ya Kurdî li Suriye, ang. Kurdish National Council, pol. Kurdyjska Rada Narodowa. 
wym dla tego podmiotu. W dniu 29 grudnia 2016 r. przyjęto konstytucję, oficjalnie tytułowaną Umową Społeczną Demokratycznej Federacji Północnej Syrii ${ }^{13}$, która zastąpiła konstytucję tymczasową z 29 stycznia 2014 r. ${ }^{14}$ Przedsięwzięcie to towarzyszyło powołaniu SDF ${ }^{15}$, czyli Syryjskich Sił Demokratycznych (koalicji wojskowej bojówek kurdyjskich, arabskich oraz innych grup etnicznych w regionie), a także SDC ${ }^{16}$, czyli Syryjskiej Rady Demokratycznej - prowizorycznego organu przypominającego parlament, w którym są reprezentowane wszystkie ośrodki polityczne zjednoczone w SDF.

Jak dotąd Federacja nie doczekała się uznania międzynarodowego, a jej reprezentacja nie została zaproszona na rozmowy pokojowe w Genewie toczące się pomiędzy uczestnikami wojny domowej w Syrii. Zaciekłym przeciwnikiem tego projektu jest Turcja, tradycyjnie niechętna powołaniu u swojej południowej granicy choćby kurdyjskiej autonomii regionalnej, a także ugrupowania islamistów walczących po stronie tzw. Państwa Islamskiego (m.in. Hayat Tahrir asz-Szam - Tahrir al-Sham). Wsparcie Rożawa otrzymała od sił amerykańskich i francuskich. Ambiwalentny jest stosunek do Federacji ze strony Syryjskiej Republiki Arabskiej. W przypadku operacji wojskowych, podejmowanych przez armie obu podmiotów przeciw dżihadystom, łączy je niepisany sojusz. W pozostałym zakresie, pomimo pojedynczych incydentów, obowiązuje neutralność (część funkcjonariuszy syryjskich wciąż zresztą rezyduje na terytorium Federacji). Nie ulega jednak wątpliwości, że po zakończeniu wojny domowej Rożawę czeka bardzo trudne zadanie - jest nim przekonanie prezydenta Baszszara al-Asada do zawarcia kompromisu politycznego.

Pomimo braku stabilności politycznej i pewnej prowizoryczności rozwiązań wciąż uważam, że DFNS zasługuje na uwagę. Ustrój, który zaprojektowano w Umowie Społecznej (US), a w szczególności federalna forma organizacji, stanowi efekt przemyślanej koncepcji opartej na konkretnej doktrynie polityczno-prawnej. W tak trudnych warunkach trudno jest, co prawda, badać praktykę ustrojową i weryfikować prawdziwość enuncjacji, niemniej sama myśl ustrojowa oraz zaproponowany projekt federalizacji i demokratyzacji Syrii bez wątpienia mogą być przedmiotem analizy.

${ }^{013}$ Social Contract of the Democratic Federalism of Northern Syria, https://vvanwilgenburg. blogspot.com/2017/03/social-contract-of-democratic.html [dostęp: 10.09.2018].

${ }^{14}$ Charter of the Social Contract, [w:] Human Rights Watch, Under Kurdish Rule. Abuses in PYD-run Enclaves of Syria, Washington 2014, s. 54-75.

${ }^{15}$ SDF (QSD, HSD) - ang. Syrian Democratic Forces, arab. Quwwāt Sūriyā al-Dīmuqrāṭ̂ya, kurd. Hêzên Sûriya Demokratîk, pol. Syryjskie Siły Demokratyczne.

16 SDC (MSD) - ang. Syrian Democratic Council, kurd. Meclîsa Suriya Demokratîk, pol. Syryjska Rada Demokratyczna. 


\section{DEMOKRATYCZNY KONFEDERALIZM JAKO DOKTRYNALNA PODBUDOWA FEDERALIZMU}

Ideologiczny fundament opisywanego projektu politycznego stanowi doktryna demokratycznego konfederalizmu, której twórcą jest Abdullah Öcalan, pochodzący z Turcji Kurd, lider uznawanej za organizację terrorystyczną Partii Pracujących Kurdystanu (PKK $)^{17}$. Do końca lat 90 . XX w. Öcalan, nazywany przez swoich zwolenników „Apo” (zdrobnienie od imienia Abdullah, ale też kurd. Apo oznaczające 'wuj', 'opiekun') $)^{18}$, wyznawał komunizm w wydaniu marksistowsko-leninowskim, wpisując się w długą tradycję ruchów lewicowo-wyzwoleńczych w krajach postkolonialnych. W zależności od koniunktury politycznej modyfikował swój program, lecz co do zasady postulował wyzwolenie wszystkich czterech części Kurdystanu (tureckiej, syryjskiej, irackiej i irańskiej) poprzez rewolucję ludową i ustanowienie socjalistycznego państwa narodowego. W ciągu ostatnich dwóch dekad ubiegłego stulecia prowadził brutalną walkę na południu Turcji, pod swoją komendą gromadząc aktywistów politycznych i nadzwyczaj sprawne oddziały partyzantów, liczące niemal 15 tys. członków ${ }^{19}$.

W 1999 r. Öcalan został zatrzymany i skazany przez sąd turecki na karę śmierci (wyrok ostatecznie zamieniono na dożywotnie pozbawienie wolności). Zaapelował wówczas o pokojowe rozwiązanie konfliktu kurdyjsko-tureckiego. Złożył samokrytykę, odcinając się od ideologii, metod działania oraz autorytarnej organizacji dotychczasowego PKK ${ }^{20}$. Wkrótce opublikował nowy manifest - Deklarację demokratycznego konfederalizmu w Kurdystanie ${ }^{21}$, będący wyznaniem

17 PKK - kurd. Partiya Karkeren Kurdistane, pol. Partia Pracujących Kurdystanu.

18 Sami określali się jako apoiści (tur. apocular), a ich ruch oraz program polityczny bywają nazywane apoizmem (apizmem).

19 Party Program of The Kurdistan Workers Party (PKK), 1995, http://apa.online.free.fr/imprimersans.php3?id_article=746 [dostęp: 1.07.2018]. Zob. A. Marcus, Blood and Belief. The PKK and The Kurdish Fight for Independence, New York-London 2017, passim; D. McDowall, A Modern History of the Kurds, London-New York 2007, s. 420 i n.; A.K. Özcan, Turkey's Kurds. A Theoretical Analysis of the PKK and Abdullah Öcalan, London-New York 2006, passim; M. van Bruinessen, Between Guerrilla War and Political Murder. The Workers' Party of Kurdistan, "MERIP. Middle East Report" 1988, No. 153, s. 40-50.

20 A. Öcalan, Prison Writings, Vol. 1: The PKK and the Kurdish Question in the $21^{\text {st }}$ Century, London 2011, s. 44 i n., 54 i n., 64 i n.; idem, War and Peace in Kurdistan. Perspectives for a Political Solution of the Kurdish Question, Cologne 2009, s. 28 i n.; idem, Democratic Nation, Cologne 2016, s. 63 i n. Por. M. Leezenberg, The ambiguities of democratic autonomy: the Kurdish movement in Turkey and Rojava, "Southeast European and Black Sea Studies" 2016, Vol. 16(4), DOI: https://doi.org/10.1080/14683857.2016.1246529, s. 676.

21 A. Öcalan, Declaration on the Democratic Solution of the Kurdish Question, Neuss 1999. Właściwie był to wydany łącznie cykl esejów filozoficznych i propagandowych. Stanowił też załącznik do pisma do Europejskiego Trybunału Praw Człowieka skarżącego wyrok sądu tureckiego jako dowód na pokojowe i demokratyczne zapatrywania skazanego. 
wiary w libertarny socjalizm, demokrację partycypacyjną, a także oddolną organizację wspólnoty (ang. grassroots). Najważniejsza kwestia jednak była związana z niepodległością. Öcalan odrzucił teraz irredentyzm, w zamian proponując autonomię w ramach istniejących granic bądź ponad tymi granicami.

Myśl ta inspirowana jest przede wszystkim komunalizmem (komunaryzmem czy municypalizmem) w wydaniu nieco zapomnianego amerykańskiego ekoanarchisty Murraya Bookchina, a w kontekście (kon)federalizmu i spojrzenia na bieg procesów historycznych - również Fernanda Braudela ${ }^{22}$. Opiera się na kilku fundamentach: krytyce państwa narodowego, demokracji partycypacyjnej, ekonomii społecznej (kooperatywizmie), ekologii społecznej (wypadkowej pomiędzy ekologią głęboką a płytką) oraz feminizmie (tzw. żineologia, kurd. jineolojî). Najwyższą wartością jest tu wolność rozumiana jako wolność polityczna - partycypacyjna i izonomiczna ${ }^{23}$.

Öcalan konstatował, że tworzenie państw narodowych prowadzi do zaprzeczenia wolności, wypaczenia demokracji i degradacji natury ${ }^{24}$. Państwo jest bowiem tworem sztucznym, służącym podporządkowaniu społeczeństwa klasie rządzącej. Wykorzystując przymus (prawo), przemoc i ideologię (religię, nacjonalizm, statolatrię), elity dążą do zapewnienia sobie władzy i wpływów materialnych. W państwie narodowym zaś procesy te intensyfikuje dążenie do konsolidacji społeczeństwa poprzez jego uniformizację (wytworzenie społeczeństwa homogenicznego). Dochodzi wówczas do prześladowań, a w najlepszym razie do dyskryminacji mniejszości. Stąd też państwo narodowe należy znieść, a pozostałe formuły suwerenności można tolerować, tylko jeśli zdecydują się na decentralizację, usieciowienie i przyznanie rozległej autonomii samorządom. Wówczas wolność czy też „demokratyczna autonomia” będzie możliwa pomimo formalnego istnienia państwa. Dużo ważniejsza od nominalnego uznania i zewnętrznych przejawów suwerenności jest autonomia faktyczna, pozwalająca społeczeństwu na realizację demokratycznych form samostanowienia. W praktyce państwowy rząd zostanie więc zastąpiony przez społeczny samorząd, a demokracja partycypacyjna uniemożliwi przerodzenie się systemu w tzw. demokrację ludową opartą na partiokracji i Leninowskim centralizmie demokratycznym ${ }^{25}$.

22 Poza Bookchinem Öcalan inspirował się pracami poświęconymi historii najnowszej Bliskiego Wschodu i marksistowską antropologią (m.in. Friedricha Engelsa, Samuela N. Kramera czy Vere'a Gordona Childe'a), a także filozofią Jeana-Jacquesa Rousseau, Lwa Trockiego, Michaiła Bakunina, Karla Poppera i Michela Foucaulta.

23 A. Öcalan, Democratic Nation, s. 12 i n., 51 i n.; idem, Democratic Confederalism, Cologne 2011, passim; idem, Liberating Life. Woman's Revolution, Cologne 2013, passim; idem, The Political Thought of Abdullah Öcalan. Kurdistan, Woman's Revolution and Democratic Confederalism, London 2017, passim.

24 Idem, Democratic Confederalism, s. 9 i n., 15 i n.

25 Idem, Democratic Nation, s. 15. 
Formą organizacyjną demokratycznej autonomii byłby demokratyczny konfederalizm, czyli samoadministracja poprzez wieloszczeblowy i zdecentralizowany system rad. Podstawową formą organizacyjną byłaby gmina, czyli komuna (kurd. civatî albo kumin, komin) zrzeszająca lokalną wspólnotę. Mieszkańcy bezpośrednio uczestniczyliby w zgromadzeniu gminnym, podejmującym decyzje we wszystkich istotnych kwestiach. Ponieważ żadna gmina nie byłaby w pełni autarkiczna, wspólnoty by się stopniowo zrzeszały, na każdym z poziomów powołując radę złożoną z delegatów ciał niższego szczebla. Rady nie byłyby nadrzędne wobec powołujących je gmin, przeciwnie - to z autonomii wspólnot czerpałyby umocowanie do działania na kolejnych, coraz wyższych szczeblach organizacji. Zrzeszenie byłoby dobrowolne, a mandat przedstawiciela byłby związany (instrukcjami i demokratyczną kontrolą). W ten sposób struktura organizacyjna miałaby charakter oddolny („od dołu ku górze”), horyzontalny, możliwie najbardziej płytki ${ }^{26}$. Sieć samorządnych skonfederowanych wspólnot, pozwalająca na pokojowe współistnienie rozmaitych grup etnicznych i religijnych, oplotłaby zaś cały Bliski Wschód, czyniąc granice istniejących państw irrelewantnymi ${ }^{27}$. Kurdowie osiągnęliby wówczas upragnioną autonomię w sposób faktyczny, bez konieczności walki o nominalne państwo. Rewolucja dokonałaby się bez użycia przemocy. Dziś wizję tę realizują rozmaite organizacje społeczne i polityczne tworzone w tzw. strukturze parasolowej i zrzeszone w Unii Wspólnot w Kurdystanie (KCK) ${ }^{28}$ oraz Narodowym Kongresie Kurdystanu (KNK ${ }^{29}$. Sprawującą władzę w Rożawie PYD należy traktować jako partię-córkę, nieformalnie zależną od PKK.

\section{DEMOKRATYCZNA FEDERACJA PÓŁNOCNEJ SYRII JAKO MODEL FEDERACJI}

Projekt powołania federacji w Północnej Syrii jest bez wątpienia wyrazem dążeń do stabilizacji politycznej. Zgodnie z obowiązującą uprzednio Konstytucją tymczasową Rożawa była początkowo konfederacją trzech kantonów (dziś: regionów) ${ }^{30}$. Administracja Demokratycznej Autonomii (DAA), czyli struktura

26 Proponowana teoria pełnomocnictwa przypomina nieco socjalistyczną teorię przedstawicielstwa. Poza Bookchinowskim komunalizmem wyraźne są tu również wpływy anarchistycznego federalizmu w ujęciu Michaiła Bakunina i Pierre'a-Josepha Proudhona, a także komunizm sowiecki.

27 A. Öcalan, Democratic Nation, s. 19 i n. Zob. także: J. Jongerden, The Kurdistan Workers ' Party (PKK). Radical Democracy and the Right to Self-Determination Beyond the Nation State, [w:] The Kurdish Question Revisited, eds. G. Stansfield, M. Shareef, London 2018, s. 245-257.

${ }^{28}$ KCK - kurd. Koma Civakên Kurdystan, pol. Unia Wspólnot w Kurdystanie.

29 KNK (KNC) - kurd. Kongreya Neteweyî ya Kurdistane, ang. Kurdistan National Congress, pol. Kongres Narodowy Kurdystanu.

30 Obecnie kantony funkcjonują jako jednostki podziału administracyjnego szczebla niższego niż regiony. Na tym poziomie nie tworzy się jednak osobnych organów samorządu lub władzy przedstawicielskiej. 
władzy przedstawicielskiej, istniała osobno dla każdej z prowincji, a poza Najwyższym Sądem Konstytucyjnym (notabene nigdy nie powołanym) nie istniały organy centralne. Odrębny system stanowiła oplatająca cały kraj sieć rad, czyli władza samorządowa. Faktycznym spoiwem kraju była stojąca na czele drugiej z wymienionych struktur Rada Ludowa Zachodniego Kurdystanu (MGRK) ${ }^{31}$. Opisywana paralelność służyła realizacji socjalistycznej idei dwuwładzy gwarantującej równoważenie się czynnika politycznego i społecznego ${ }^{32}$. W teorii miało to prowadzić do petryfikacji stanu permanentnej rewolucji, w którym władza de iure nigdy nie byłaby w pełni skonsolidowana, a autonomia nie mogłaby się zamienić w państwo. W praktyce natomiast wynikało to z pewnej tymczasowości podyktowanej koncentracją na obronie przed tzw. Państwem Islamskim oraz nieuregulowanymi relacjami z Damaszkiem.

Z czasem, gdy sytuacja polityczna i militarna wymusiła na Kurdach bardziej efektywne zarządzanie kontrolowanym terytorium, a także rezygnację z radykalizmu, zdecydowano się na częściową integrację obu struktur i upodobnienie autonomii do konwencjonalnych podmiotów prawa międzynarodowego o ustroju federalnym. Obecnie de iure istnieją też organy centralne, choć ze względu na prowadzone działania wojenne wyborów do parlamentu federalnego jeszcze nie przeprowadzono. Co istotne, porządek ten nie ogranicza się do Zachodniego Kurdystanu (zasięgiem terytorialnym) ani do Kurdów (co do tożsamości narodowej), lecz może obejmować dowolną powierzchnię, na której samorządne wspólnoty rozmaitych grup etnicznych, społecznych i religijnych wyrażą wolę przystąpienia do Umowy Społecznej. Na początku września 2018 r. SDC powołało tymczasowe struktury dla znajdujących się dotychczas pod jej kontrolą i wyzwolonych w ostatnim czasie prowincji, które nazwała Administracją Demokratycznej Autonomii w Północnej i Wschodniej Syrii (w przypadku utrzymania terenów na wschodzie Syrii należy spodziewać się zmiany nazwy autonomii na „Demokratyczną Federację Północnej i Wschodniej Syrii") ${ }^{33}$.

Explicite zadeklarowano udział $\mathrm{w}$ państwie syryjskim. DFNS jako kraj związkowy Federacji Syrii (projektowanej, jako że państwo to w tej formie nie

${ }^{31}$ MGRK - kurd. Meclîsa Gel a Rojavaye Kurdistane, pol. Rada Ludowa Zachodniego Kurdystanu.

32 Oprócz samorządu terytorialnego MGRK zrzeszała również samorząd organizacji społecznych i zawodowych oraz reprezentację komponentów etnicznych i wyznaniowych, które powoływali apoiści zorganizowani w ruchu społecznym TEV-DEM (kurd. Tevgera Civaka Demokratîk, pol. Ruch na rzecz Społeczeństwa Demokratycznego). TEV-DEM to apoistowska koalicja partii (do sierpnia 2018 r.) i innych organizacji społecznych (zrzeszeń i stowarzyszeń obywatelskich) koordynująca przemiany polityczne w Rożawie.

${ }_{33}$ Zob. W. van Wilgenburg, New administration formed for northeastern Syria, www.kurdistan24.net/en/news/c9e03dab-6265-4a9a-91ee-ea8d2a93c657 [dostęp: 10.09.2018]; [A.H.], Final Statement of Autonomous Administration of North-East Syria, http://hawarnews.com/en/haber/finalstatement-of-autonomous-administration-of-north-east-syria-h3608.html [dostęp: 10.09.2018]. 
istnieje ${ }^{34}$ ) posługuje się (obok swoich) syryjską flagą i godłem, a obowiązkiem każdego obywatela jest troska o byt obu podmiotów (tekst przysięgi określony w art. 6 US). Dodatkowo funkcję łącznika pełni art. 71 US odwołujący się do przyszłej syryjskiej demokratycznej ustawy zasadniczej, którą Rożawa ratyfikuje tylko dobrowolnie i w której „,na wszystkich poziomach zostaną określone wzajemne relacje pomiędzy Demokratyczną Federacją Północnej Syrii a Demokratyczną Federacją Syrii”. Umowa Społeczna nie proklamuje więc niepodległości i w zasadzie przypomina konstytucje stanowe w USA, z tym że „stan” jest tu sam w sobie federacją, która zrzesza samorządne regiony. Ustrój DFNS ma zaś stanowić, jak wspomniałem, wzór organizacji politycznej dla całej Syrii po zakończeniu wojny domowej.

Należy wskazać na co najmniej cztery aspekty opisywanego zabiegu. Po pierwsze, Umowę Społeczną należy traktować nie tylko jako (przynajmniej nominalnie) akt najwyższego prawa obowiązującego w Rożawie (w teorii jest ona zresztą bezpośrednio skuteczna, w praktyce dość często jednak naruszana), ale także jako projekt, który zostanie w przyszłości poddany negocjacjom ${ }^{35}$. Po drugie, konsekwentne deklarowanie się jako część Syrii częściowo zabezpiecza Rożawę przed oskarżeniami o separatyzm i dezintegrację Syrii. Po trzecie, widoczne jest wyraźne dążenie do realizacji demokratycznego konfederalizmu jako środka do pokojowego wspólistnienia wszystkich ludów zamieszkujących Syrię. Powołanie federacji tylko pozornie stanowi bowiem sprzeczność z konfederalizmem Öcalana, ponieważ koncepcja ta nie zakładała utworzenia związku suwerennych państw, lecz autonomiczną demokrację istniejącą niezależnie od nominalnych struktur. Jeżeli więc wybrana forma ustrojowa pozwala na realizację samorządu społecznego, to nie zachodzi sprzeczność pomiędzy demokratyczną federacją jako porządkiem politycznym a demokratycznym konfederalizmem jako doktryną. I wreszcie po czwarte, przedstawienie modelu DFNS ma również (a może przede wszystkim) wymiar propagandowy. Autorom Umowy Społecznej równie mocno jak na organizacji ładu polityczno-prawnego zależało na wyłożeniu wartości, które przyświecają koalicji SDF. Do najważniejszych zasad ustrojowych DFNS (poza omawianą tu zasadą federalizmu) należą: zasada społeczeństwa demokratycznego, zasada pluralizmu, zasada równości (właściwie na wyodrębnienie zasługuje tu zasada równości kobiet i mężczyzn), zasada sprawiedliwości społecznej, zasada godności człowieka, zasada ekonomii społecznej oraz zasada społeczeństwa ekologicznego. Pośród wartości, które opisywany porządek cele-

34 Zob. np. The Project of a Democratic Syria, TEV-DEM, 15 February 2015, https://peaceinkurdistancampaign.com/resources/rojava/the-project-of-a-democratic-syria [dostęp: 29.08.2018].

${ }^{35}$ Ze względu na obiektywne okoliczności część jej postanowień nie została w pełni wdrożona (np. reforma wymiaru sprawiedliwości polegająca na zastąpieniu sądów ludowych radami sprawiedliwości), w pozostałym zakresie rzeczywistość już wyprzedziła prawo (np. reforma administracyjna polegająca na powołaniu regionów o statusie dotychczasowych kantonów). 
bruje, należy wymienić: wolność, równość, solidaryzm, ochronę kobiet, ochronę przyrody i zasobów naturalnych oraz godność jednostki. Aksjologię polityczną i prawną opisywanego systemu uzupełnia współczesna teoria praw człowieka, pojmowanych jako prawa podstawowe i podmiotowe. Umowa Społeczna odwołuje się do tego katalogu aż czterokrotnie: w Preambule i art. 68 ust. 4 (wytyczna), art. 17 (wartości i zasady ustrojowe), art. 54 ust. 4 (międzynarodowe konwencje praw człowieka jako źródło praw podmiotowych), przy czym są to uniwersalne prawa człowieka, a nie te, które tak często rozpoznają państwa muzułmańskie ${ }^{36}$.

Za suwerena należy w DFNS uważać ludy Północnej Syrii (wspólnoty etniczne i religijne) złączone w jednym narodzie demokratycznym (społeczeństwie obywatelskim), a za cel organizacji - pokojowe współistnienie, sprawiedliwość społeczną i wspólne dobro. Władzę sprawuje on nie tylko poprzez zwierzchnictwo nad władzą przedstawicielską, jak przyjęto $\mathrm{w}$ demokracjach liberalnych, lecz przede wszystkim bezpośrednio w samorządzie i poprzez tzw. instytucje demokracji bezpośredniej. System rządów wyłaniający się z Umowy Społecznej i enuncjacji jej autorów ${ }^{37}$ to demokracja bezpośrednia uzupełniana mechanizmami demokracji przedstawicielskiej, a więc model „półbezpośredni”, choć realizm nakazuje powściągliwość wobec oficjalnych deklaracji (wówczas byłaby to demokracja przedstawicielska uzupełniana rozległymi mechanizmami demokracji bezpośredniej). Dość czytelne są inspiracje systemem szwajcarskim. Brak tu horyzontalnego podziału władz, a zgromadzenie jest organem nadrzędnym wobec pozostałych, dysponując - obok kompetencji służących realizacji funkcji prawodawczej, kreacyjnej i kontrolnej uprawnieniami tradycyjnie przypisywanymi egzekutywie (np. kierownictwem nad siłami zbrojnymi). Władza wykonawcza, sprawowana przez rady wykonawcze, realizuje nie tylko ustawy, ale także dyrektywy, polityki, a nawet akty indywidualne wydawane przez parlamenty ${ }^{38}$. Ze względu na supremację zgromadzenia należy ten system rządów określić jako komitetowy ${ }^{39}$.

Ustrój samorządu oparty jest na zasadach decentralizacji, partycypacji obywatelskiej i organizacji horyzontalnej. Umowa Społeczna przewiduje bardzo sze-

36 Cairo Declaration on Human Rights in Islam, August 5, 1990, http://hrlibrary.umn.edu/ instree/cairodeclaration.html [dostęp: 10.09.2018]; Arab Charter on Human Rights, May 22, 2004, http://hrlibrary.umn.edu/instree/loas2005.html?msource=UNWDEC19001\&tr=y\&auid=3337655 [dostęp: 10.09.2018].

37 The Internal System of the Communes in Rojava, www.aymennjawad.org/2018/04/the-internal-system-of-the-communes-in-rojava [dostęp: 6.08.2018].

38 Dominację zgromadzenia przypieczętowuje domniemanie kompetencyjne. Co prawda, organy stanowiące składają się tylko z jednej izby i nie pełnią bezpośrednio funkcji orzeczniczych, lecz powołują i kontrolują organy władz sądowniczych, a w skład rad lokalnych wchodzą tzw. komitety pojednawcze - organy orzecznicze realizujące alternatywne formy rozstrzygania sporów (ADR).

39 Zob. B. Banaszak, Porównawcze prawo konstytucyjne współczesnych państw demokratycznych, Warszawa 2007, s. 358. 
rokie prawa do samoadministrowania i zrzeszania się (inną kwestią jest realizacja tych postanowień na płaszczyźnie ustawowej). Co istotne, nie tyle nadaje się, co potwierdza się niezależność gminy ${ }^{40}$. Jako podstawowa forma organizacji społecznej może ona być wspierana przez organy wyższych szczebli samorządu bądź władze przedstawicielskie jedynie w sprawach wykraczających poza zasięg lokalny lub zdolność wspólnoty do ich rozwiązania ${ }^{41}$. Domniemanie kompetencyjne spoczywa więc na jednostkach najniższego szczebla ${ }^{42}$. Mamy tu do czynienia nie tylko z oddolną konstrukcją, ale też z naturalistyczną koncepcją samorządu.

W tym stanie rzeczy nie powinno budzić wątpliwości, że system Federacji charakteryzuje się daleko posuniętą samorządnością i decentralizacją ${ }^{43}$. Należy jednak pamiętać, że federalizm jako forma ustrojowa czy zasada konstytucyjna wykracza poza zwykłe przekazanie kompetencji jednostkom samorządu terytorialnego. Zakłada on szczególny status krajów związkowych oraz potrzebę jego ochrony na płaszczyźnie konstytucyjnej (naruszenie autonomii samorządu stanowi wówczas naruszenie ustawy zasadniczej), a w przypadku etnofederalizmu - również społeczny podział władzy. Oba kryteria zostały w ustroju DFNS spełnione.

Jeżeli chodzi o federalizm segmentowy, to komponentom społecznym, etnicznym i wyznaniowym gwarantuje się pełnię praw politycznych, prawa do samorządu, swobody w zakresie praktykowania wybranego obrządku, nauczania w dowolnym języku i krzewienia kultury ojczystej (w Rożawie obowiązują trzy języki urzędowe: kurdyjski - kurmandżi, arabski i syryjski - współczesny asyryjski, choć nie w każdej prowincji administracja posługuje się wszystkimi naraz ${ }^{44}$. Ponadto rezerwuje się dla nich aż 40\% mandatów we wszystkich bezpośrednio

40 Gmina łączy od 30 do 200 (w dużych miastach nawet 500) sąsiadujących ze sobą gospodarstw domowych. Należą do niej wszyscy pełnoletni mieszkańcy. Posiadają oni prawo do bezpośredniego udziału w zgromadzeniu gminnym, a także wybierania i bycia wybieranym do komitetu koordynującego gminy oraz uczestniczenia w pracach rozmaitych komisji tego komitetu.

${ }^{41}$ Samorząd terytorialny funkcjonuje w Rożawie na trzech szczeblach: gminnym, dzielnicowym (resp. małych miast i wspólnot wiejskich) oraz dystryktowym. Na każdym z nich tworzy się organy stanowiące i wykonawcze. Horyzontalny układ struktury władzy w regionach sprawia, że jednostki niższego szczebla stosują przepisy Umowy Społecznej oraz ustawy federalne i regionalne, w pozostałym zakresie zaś nie są podporządkowane jednostkom administracyjnym wyższego szczebla.

42 Organy lokalnych wspólnot etnicznych i religijnych mogą nawet zgłosić sprzeciw wobec aktów wykonawczych władz przedstawicielskich. W przypadku braku porozumienia pomiędzy samorządem a władzami regionu bądź Federacji akt administracyjny poddaje się pod głosowanie w referendum członkom danej wspólnoty (art. 74 US), a jeżeli zostaje on odrzucony - sprawę rozpatruje sąd konstytucyjny (art. 75 US).

43 Szerzej na temat samorządu zob. T. Schmidinger, Rojava. Revolution, War, and the Future of Syria's Kurds, London 2018, s. 134 i n., passim; M. Knapp, A. Flach, E. Ayboğa, Revolution in Rojava. Democratic Autonomy and Women's Liberation in Syrian Kurdistan, London 2016, s. 84 i n.

44 Zgodnie $\mathrm{z}$ art. 33 i art. 54 ust. 8 US. 
wybieralnych organach kolegialnych, począwszy od rady dzielnicy, na parlamencie federalnym kończąc ${ }^{45}$ (w przypadku gminy nie jest to konieczne, ponieważ zgromadzenie gminne tworzą wszyscy mieszkańcy wspólnoty; dodatkowo zakłada się, że gminy są zazwyczaj jednolite). W organach wykonawczych, które są kreowane przez zgromadzenia, rady i parlamenty (regionalne, nazywane Zgromadzeniami Ludów, oraz federalny, nazywany Konferencją Ludów Demokratycznych), a także w Radzie Umowy Społecznej (sądzie konstytucyjnym) i w federalnej Radzie do spraw Mediów oraz Działalności Wydawniczej i Informacyjnej obowiązuje ogólna dyrektywa, by obsadzając poszczególne urzędy, mieć na względzie zasadę pluralizmu ${ }^{46}$.

Na obowiązywanie zasady federalizmu w klasycznym sensie wskazuje już nazwa autonomii oraz odwołanie się w tytule ustawy zasadniczej do kontraktuali$\mathrm{zmu}^{47}$. Dalsze potwierdzenie teza o jej istnieniu znajduje zarówno w Preambule Umowy Społecznej, która powołuje się na samorządność i dobrowolną współpracę regionów, jak i w art. 5-6, 8 oraz 47 tego aktu. Konstytucja przyznaje regionom, na które składają się co najmniej dwa kantony i cztery dystrykty, szczególny status. Podstawową komórką oddolnej organizacji społecznej jest oczywiście gmina, lecz w przypadku struktury władzy przedstawicielskiej jest to region. Panuje bowiem przekonanie, że wspólnoty lokalne łączą się w regionalną sieć samorządu terytorialnego zgodnie z profilem historycznym, etnicznym, ekonomicznym i kulturowym (art. 53 US). Ważnym czynnikiem integrującym jest więc komplementarność i autarkia poszczególnych prowincji ${ }^{48}$. Dlatego do regionów, a nie do władz federalnych, należy rozporządzanie zasobami naturalnymi leżącymi na ich terytorium i wpływami z ich sprzedaży (art. 54 ust. 3, art. 77 US) oraz określanie zasad inwestycji kapitału zagranicznego (art. 78 US). Poza Irakiem, gdzie zresztą stanowi to przedmiot kontrowersji, żaden inny „etnofederalizm” nie zdecydował się dotychczas na tak postępowe rozwiązanie.

Zgodnie z art. 7 i 21 US regiony są samorządne. Dobrowolnie łączą się w Federację i koordynują swoje starania na rzecz dobrobytu i pokojowego wspótistnienia ludów zamieszkujących Północną Syrię, a władze federalne DFNS obowiązane są to prawo do samorządu uszanować (art. 57 US). Zachowują daleko idącą autonomię, same stanowią o sprawach ich dotyczących: uchwalają ustawy, powołują osobne struktury administracji, utrzymują niezależne organy wymiaru sprawiedliwości. Samodzielnie troszczą się też o realizację socjalnych, ekono-

45 Art. 50, art. 55 ust. 2, art. 58 ust. 3 US. Dokładny podział tych $40 \%$ mandatów określają akty organiczne wydane przez tymczasowe organy stanowiące danego szczebla.

${ }_{46}$ Art. 16, art. 63 ust. 2, art. 65 US.

47 Mamy tu jednak do czynienia z umową społeczną zawieraną pomiędzy wspólnotami ludów zamieszkujących Północną Syrię, a nie regionami.

48 Samowystarczalność per se jest oczywiście fikcją. Chodzi raczej o zjednoczenie wspólnot w regionie we wspólnie rozpoznawanym interesie. 
micznych, kulturalnych i edukacyjnych potrzeb swoich obywateli, w szczególności o redystrybucję dochodu społecznego (art. 54 ust. 3 US). Umowa Społeczna milczy na temat materii zastrzeżonych dla regulacji władz regionalnych i federalnych, lecz realizm nakazuje uznać, że obowiązuje system ustawodawstwa konkurencyjnego, przy zachowaniu zwierzchnictwa parlamentu federalnego, ale i domniemania kompetencji po stronie krajów związkowych. W granicach dopuszczalnych przez Umowę Społeczną regiony same utrzymują stosunki dyplomatyczne oraz finansują i organizują stacjonujące na ich terytorium siły zbrojne ${ }^{49}$. Tak jak w każdej federacji, w DFNS zakłada się rozdzielenie budżetów centralnego i krajów związkowych, a dodatkowym źródłem dochodów regionów pozostają subwencje z budżetu centralnego (art. 54 ust. 2 US) ${ }^{50}$.

Są to bardzo szeroko i ogólnie określone kompetencje. Trudno oczekiwać, by w praktyce zakres działania władz regionalnych i federalnych nie nakładał się na siebie. Tymczasem, by zasada federalizmu mogła zostać wcielona w życie, niezbędne jest ściślejsze konstytucyjne określenie (rozdzielenie) kompetencji w ramach podziału wertykalnego. Uderza choćby brak w konstytucji klauzuli supremacyjnej. W przyszłości może to doprowadzić do tarć, choć jak na razie ze względu na fakt, że inwazja turecka na Afrin uniemożliwiła przeprowadzenie wyborów do Konferencji Ludów Demokratycznych - nie ma to większego znaczenia. Działająca tymczasowo SDC i powołany przez nią prowizoryczny rząd zajmują się głównie kwestiami o znaczeniu strategicznym: wojną i stosunkami dyplomatycznymi z władzami w Damaszku.

Ustawa zasadnicza przewiduje także system hamulców i równowagi pomiędzy wertykalnie podzielonymi władzami. Wspomniałem już o domniemaniu kompetencji regionów oraz nadrzędności ustaw federalnych. Ponadto zgodnie $\mathrm{z}$ art. 62 ust. 8 US ministerstwa federalne sprawują nadzór formalny nad wykonywaniem zadań publicznych przez ministerstwa regionalne oraz koordynują i organizują współpracę pomiędzy resortami w krajach związkowych, a ustawy federalne są nadrzędne wobec regionalnych. Innym rozwiązaniem tego typu jest wynikająca z art. 61 ust. 2 US kompetencja rad wykonawczych (rządów) regionalnych do nominowania członków federalnej Rady Wykonawczej (zatwierdza ich następnie Konferencja Ludowa, czyli parlament federalny $)^{51}$. Kolejny hamu-

49 Art. 54 ust. 5 US. Oczywiście tylko Konferencja Ludów Demokratycznych posiada kompetencję do ogłaszania stanu wojny i pokoju.

50 Warto także zauważyć, że w postanowieniach dotyczących sił zbrojnych i rozporządzania zasobami naturalnymi tkwi ukryty postulat zapewnienia analogicznej autonomii DFNS po zjednoczeniu z Damaszkiem. Własna armia oraz kontrola nad największymi zasobami ropy naftowej i wody w Syrii de facto pozwoliłyby Rożawie na prowadzenie samodzielnej polityki i postawiłyby ją wobec prezydenta Al-Asada w pozycji partnera.

51 Jednocześnie istnieje wymóg, by co najmniej $80 \%$ składu rządu federalnego stanowili deputowani do Konferencji Ludowej, a współprzewodniczący regionalnych rad wykonawczych nie mają prawa być kandydatami na współprzewodniczących federalnej Rady Wykonawczej. 
lec ustrojowy przewiduje art. 75 US, który stwierdza, iż w przypadku, gdy decyzje (prawo stanowione bądź akty wykonawcze) regionów lub wspólnot lokalnych są sprzeczne z interesem powszechnym Federacji bądź postanowieniami Umowy Społecznej, federalna Rada Wykonawcza może zaskarżyć je do Rady Umowy Społecznej (sądu konstytucyjnego), która orzekać będzie o ich zasadności bądź zgodności z ustawą zasadniczą. Analogiczne uprawnienie przysługuje samorządowi. Zgodnie z art. 66 ust. 4 US Rada Umowy Społecznej rozstrzyga wszelkie spory pomiędzy władzami federalnymi a władzami regionalnymi. Bez przyznania wspólnotom i regionom prawa do wniesienia skargi konstytucyjnej trudno by było wyobrazić sobie realizację samorządności i federalizmu. W parlamencie federalnym DFNS brak natomiast drugiej izby, która (np. na zasadzie symetrii) reprezentowałaby regiony. Wreszcie niejasne jest, czy regiony posiadają (choćby w teorii) możliwość wystąpienia z Federacji.

Interesujące jest to, że regiony nie są w Umowie Społecznej wymienione z nazwy, co może wskazywać na brak gwarancji ich istnienia i dopuszczalność ustawowej ingerencji w ich formację. Tak jednak nie jest. Ustawa zasadnicza nie odnosi się do konkretnych regionów, ponieważ rozpoznaje suwerenność ludów i prawo do samostanowienia. Samorządne regiony tworzone są bowiem dobrowolnie, spontanicznie i oddolnie, a formuła DFNS jest otwarta na nowych członków. Próba sztywnego ustalenia liczby regionów byłaby zresztą niepraktyczna w warunkach płynnej sytuacji politycznej i militarnej w Północnej Syrii. Federacja gwarantuje natomiast fizyczną egzystencję (bezpieczeństwo) tych autonomicznych regionów, które tworzą koalicję, poprzez zobowiązanie się do ich obrony militarnej (zob. art. 54 ust. 6 US).

\section{PODSUMOWANIE}

Zdaniem Vitorii Federici Rożawa stanowi obecnie najprawdopodobniej jedyny endogeniczny projekt budowy podmiotowości politycznej, który ma jakiekolwiek szanse zakończyć się sukcesem ${ }^{52}$. Chociaż DFNS dotychczas nie doczekała się uznania międzynarodowego, powołane przez TEV-DEM struktury zdołały ustanowić autonomię wykonującą wszystkie istotne zadania publiczne, które tradycyjnie przypisuje się państwu (włączając w to nie tylko skuteczną obronę przed zagrożeniami zewnętrznymi, ale nawet system szkolnictwa wyższego). Autonomia kurdyjska ze swoją sprawną administracją, oddziałami samoobrony oraz wsparciem dla uchodźców (słynny Camp Newroz) prima facie jawi się jako ostoja normalności w regionie wstrząsanym kolejnymi katastrofami humanitarnymi. W tym kontekście Rewolucja w Rożawie wskazuje na nowe sposoby rozumienia

52 V. Federici, The Rise of Rojava. Kurdish Autonomy in the Syrian Conflict, "The SAIS Review of International Affairs" 2015, Vol. 35(2), DOI: https://doi.org/10.1353/sais.2015.0023, s. 83. 
i realizacji procesu budowy społeczeństw obywatelskich i państw (ang. nationbuilding, statebuilding). Nade wszystko zaś potwierdza potrzebę dalszego rozwijania koncepcji federalizacji jako środka do rozładowania napięć na Bliskim Wschodzie.

Pomimo tych relatywnych powodzeń Rożawa wciąż musi jednak mierzyć się z licznymi trudnościami, zarówno na płaszczyźnie wewnętrznej (problemy związane ze sprawiedliwością okresu przejściowego i rule of law, trudności ekonomiczne), jak i zewnętrznej (embargo handlowe, inwazja turecka na Afrin, nadchodzące pertraktacje z władzami w Damaszku). W tym kontekście nie sposób pominąc wciąż dostrzegalnego zdominowania struktur demokracji bezpośredniej i sceny politycznej przez jeden ośrodek. PYD pozostaje główną siłą polityczną w kraju, a możliwość wyboru przez obywateli innego modelu ustrojowego wydaje się wykluczona. Jako zagrożenie dla wolności należy postrzegać również brak trójpodziału władz publicznych. Fakty te skłaniają niektórych komentatorów do nader krytycznego stanowiska, w myśl którego TEV-DEM jest organizacją fasadową, a demokracja bezpośrednia to fikcja ${ }^{53}$. Także zdaniem polskiej badaczki, Marii Giedz, „PYD chce rządów absolutnych, likwidując przeciwników”54. Dość przypomnieć, że w przeszłości wiele reżimów autorytarnych czy wręcz totalitarnych o lewicowej proweniencji zwoływało lokalne zgromadzenia ludowe w celu legitymizacji niedemokratycznych rządów (np. na Kubie w latach 1960-1976). Istnieje więc zagrożenie, że demokracja oddolna jest w Rożawie tylko pozornie spontaniczna (tzw. astroturfing) ${ }^{55}$.

Demokracji w Rożawie nie sposób określić mianem liberalnej, choć jak dotychczas niewłaściwe wydaje się też stwierdzenie, że jest ona totalitarna. Pod wieloma względami porządek Federacji można uznać za pozostający w anokratycznym zawieszeniu pomiędzy autorytaryzmem a konstytucyjną demokracją (byłby to więc tzw. reżim hybrydowy). Jednym z kluczowych, jak sądzę, czynników przeciwstawiających się osunięciu Rożawy w przepaść autorytaryzmu oraz wewnętrznych konfliktów na tle etnicznym i religijnym będzie przestrzeganie wyrażonej w Umowie Społecznej zasady federalizmu.

53 A. Baczko, G. Dorronsoro, A. Quesnay, Civil War in Syria. Mobilization and Competing Social Orders, Cambridge 2017, s. 169 i n.

54 M. Giedz, Szanse Kurdów na niepodległe państwo, „Pogranicze. Polish Borderlands Studies” 2016, t. 4(1), DOI: https://doi.org/10.25167/ppbs482, s. 138.

55 Zob. także: Human Rights Watch, op. cit., passim; Amnesty International, We Had Nowhere Else to Go. Forced Displacement and Demolitions in Northern Syria, London 2015, s. 6 i n. 


\section{BIBLIOGRAFIA}

[A.H.], Final Statement of Autonomous Administration of North-East Syria, http://hawarnews. $\mathrm{com} / \mathrm{en} / \mathrm{haber} /$ final-statement-of-autonomous-administration-of-north-east-syria-h3608.html [dostęp: 10.09.2018].

Amnesty International, We Had Nowhere Else to Go. Forced Displacement and Demolitions in Northern Syria, London 2015.

Arab Charter on Human Rights, May 22, 2004, http:/hrlibrary.umn.edu/instree/loas2005.html?mso urce=UNWDEC19001\&tr=y\&auid=3337655 [dostęp: 10.09.2018].

Baczko A., Dorronsoro G., Quesnay A., Civil War in Syria. Mobilization and Competing Social Orders, Cambridge 2017.

Banaszak B., Porównawcze prawo konstytucyjne wspótczesnych państw demokratycznych, Warszawa 2007.

Bruinessen M. van, Between Guerrilla War and Political Murder. The Workers' Party of Kurdistan, "MERIP. Middle East Report" 1988, No. 153.

Cairo Declaration on Human Rights in Islam, August 5, 1990, http://hrlibrary.umn.edu/instree/cairodeclaration.html [dostęp: 10.09.2018].

Charter of the Social Contract, [w:] Human Rights Watch, Under Kurdish Rule. Abuses in PYD-run Enclaves of Syria, Washington 2014.

Choudhry S., Hume N., Federalism, Devolution and Secession: From Classical to Post-conflict Federalism, [w:] Handbook on Comparative Constitutional Law, eds. T. Ginsburg, R. Dixon, Cheltenham-Northhampton 2011.

Elazar D.J., Exploring Federalism, Tuscaloosa-London 1987.

Federici V., The Rise of Rojava. Kurdish Autonomy in the Syrian Conflict, "The SAIS Review of International Affairs" 2015, Vol. 35(2), DOI: https://doi.org/10.1353/sais.2015.0023.

Ghai Y., Ethnicity and Autonomy. A Framework for Analysis, [w:] Autonomy and Ethnicity. Negotiation Competing Claims in Multi-ethnic States, ed. Y. Ghai, Cambridge 2000.

Giedz M., Szanse Kurdów na niepodległe państwo, „Pogranicze. Polish Borderlands Studies” 2016, t. 4(1), DOI: https://doi.org/10.25167/ppbs482.

Hale H., Divided We Stand. Institutional Sources of Ethnofederal State Survival and Collapse, "World Politics" 2004, Vol. 56(2), DOI: https://doi.org/10.1353/wp.2004.0011.

Horowitz D., Making Moderation Pay. The Comparative Politics of Ethnic Conflict Management, [w:] Conflict and Peacemaking in Multiethnic Societies, ed. J.V. Montville, Lexington 1990.

Human Rights Watch, Under Kurdish Rule. Abuses in PYD-run Enclaves of Syria, Washington 2014.

Jongerden J., The Kurdistan Workers' Party (PKK). Radical Democracy and the Right to Self-Determination Beyond the Nation State, [w:] The Kurdish Question Revisited, eds. G. Stansfield, M. Shareef, London 2018.

Knapp M., Flach A., Ayboğa E., Revolution in Rojava. Democratic Autonomy and Women's Liberation in Syrian Kurdistan, London 2016.

Kymlicka W., Federalism and Secession. At Home and Abroad, "Canadian Journal of Law and Jurisprudence" 2000, Vol. 13(2), DOI: https://doi.org/10.1017/S0841820900000400.

Kymlicka W., Is Federalism a Viable Alternative to Secession, [w:] Theories of Secession, ed. P.B. Lehning, London-New York 1998.

Leezenberg M., The ambiguities of democratic autonomy: the Kurdish movement in Turkey and Rojava, "Southeast European and Black Sea Studies" 2016, Vol. 16(4),

DOI: https://doi.org/10.1080/14683857.2016.1246529.

Lijphart A., Democracy in Plural Societies. A Comparative Exploration, New Haven-London 1977.

Mallat C., Federalism in the Middle East and Europe, "Case Western Reserve Journal of International Law" 2003, Vol. 35(1).

Marcus A., Blood and Belief. The PKK and The Kurdish Fight for Independence, New York-London 2017. 
McDowall D., A Modern History of the Kurds, London-New York 2007.

McGarry J., O’Leary B., Must Pluri-national Federations Fail?, "Ethnopolitics" 2009, Vol. 8(1), DOI: https://doi.org/10.1080/17449050902738838.

Öcalan A., Declaration on the Democratic Solution of the Kurdish Question, Neuss 1999.

Öcalan A., Democratic Confederalism, Cologne 2011.

Öcalan A., Democratic Nation, Cologne 2016.

Öcalan A., Liberating Life. Woman's Revolution, Cologne 2013.

Öcalan A., Prison Writings, Vol. 1: The PKK and the Kurdish Question in the 21 ${ }^{\text {st }}$ Century, London 2011.

Öcalan A., The Political Thought of Abdullah Öcalan. Kurdistan, Woman's Revolution and Democratic Confederalism, London 2017.

Öcalan A., War and Peace in Kurdistan. Perspectives for a Political Solution of the Kurdish Question, Cologne 2009.

Özcan A.K., Turkey's Kurds. A Theoretical Analysis of the PKK and Abdullah Öcalan, London-New York 2006.

Party Program of The Kurdistan Workers Party (PKK), 1995, http://apa.online.free.fr/imprimersans. php3?id_article=746 [dostęp: 1.07.2018].

Roeder P.G., Ethnofederalism and the Mismanagement of Conflicting Nationalisms, "Regional \& Federal Studies" 2009, Vol. 19(2), DOI: https://doi.org/10.1080/13597560902753420.

Schmidinger T., Rojava. Revolution, War, and the Future of Syria's Kurds, London 2018.

Social Contract of the Democratic Federalism of Northern Syria, https://vvanwilgenburg.blogspot. com/2017/03/social-contract-of-democratic.html [dostęp: 10.09.2018].

The Internal System of the Communes in Rojava, www.aymennjawad.org/2018/04/the-internal-system-of-the-communes-in-rojava [dostęp: 6.08.2018].

The Project of a Democratic Syria, TEV-DEM, 15 February 2015, https://peaceinkurdistancampaign.com/resources/rojava/the-project-of-a-democratic-syria [dostęp: 29.08.2018].

Versteeg M., Federalism in the Middle East. A Collection of Essays, www.lawfareblog.com/federalism-middle-east-collection-essays [dostęp: 10.09.2018].

Wilgenburg W. van, New administration formed for northeastern Syria, www.kurdistan24.net/en/ news/c9e03dab-6265-4a9a-91 ee-ea8d2a93c657 [dostęp: 10.09.2018].

\section{SUMMARY}

The article is devoted to the federal system in the Democratic Federation of Northern Syria (North and East Syria), or the so-called Rojava. The case of this system is for many reasons special: on the one hand, it realizes the concept of ethnofederalism; on the other hand, it realizes the doctrine of democratic confederalism, i.e. political thought of Abdullah Öcalan. Democratic confederalism, referring largely to the communalism and municipalism of Murray Bookchin, advocates the implementation of a new order in the Middle East, in which various self-administrating ethnic and religious communities could co-exist in a confederal network based on the principles of participatory democracy, legal pluralism, federalism, equality of women and men, ecology and the social economy. According to its proponents, it leads to peace: first in Syria and later in the entire Middle East. federalism

Keywords: Rojava; Abdullah Öcalan; Murray Bookchin; democratic confederalism;

\section{STRESZCZENIE}

Artykuł jest poświęcony systemowi federalnemu w Demokratycznej Federacji Północnej Syrii (Północnej i Wschodniej Syrii), tzw. Rożawie. System ten stanowi przypadek szczególny: z jednej 
strony ze względu na realizację koncepcji etnofederalizmu, z drugiej zaś z uwagi na zakorzenienie w doktrynie demokratycznego konfederalizmu (tj. myśli politycznej Abdullaha Öcalana). Demokratyczny konfederalizm, nawiązując w dużej mierze do komunalizmu i municypalizmu Murraya Bookchina, opowiada się za realizacją na Bliskim Wschodzie nowego ładu, w którym rozmaite wspólnoty etniczne i religijne mogłyby w ramach swoich odrębnych, lecz połączonych ze sobą w konfederalną sieć, organizacji realizować model demokracji partycypacyjnej i pluralizmu prawnego. Porządek ten, oparty na zasadach demokracji, federalizacji, równouprawnienia kobiet i mężczyzn, ekologii oraz ekonomii społecznej, ma prowadzić do wygaszenia istniejących konfliktów i pokojowej współpracy pomiędzy społecznościami - najpierw Syrii, a później całego regionu.

Słowa kluczowe: Rożawa; Abdullah Öcalan; Murray Bookchin; demokratyczny konfederalizm; federalizm 